\title{
O DUPLO VÍNCULO ENTRE A DÁDIVA RELIGIOSA E MEDIÁTICA
}

\author{
The double bind between the religious and mediatized religious
}

El doble vínculo entre la dávida religiosa y la mediática

Jairo Ferreira

Professor Titular 1 - PPGCC - UNISINOS

jferreira@unisinos.br

Dinis Ferreira Cortes

Doutorando. PPGCC-UNISINOS

dinisfcortes@gmail.com

\section{Resumo}

Este artigo resulta de uma investigação referenciada em dois processos de pesquisa. Por um lado, a pesquisa teórica sobre as relações entre mediatização e a problemática do duplo vínculo, conforme a abordagem de Watzlawick et al. (1972). Essa perspectiva é mobilizada teoricamente como referência para a problematização comunicacional no âmbito das hipóteses sobre a mediatização. Por outro lado, o artigo condensa resultados de uma pesquisa sobre um fenômeno mediático-religioso, o do movimento carismático no Brasil liderado por Padre Robson de Oliveira, a partir de um campo de observação que compreende dois programas televisivos. As inferências apresentadas neste artigo se referem à participação dos devotos em contexto religioso, à configuração do circuito mediático construído e à constituição do Padre Robson em líder carismático, referenciado em processos mediáticos retroalimentados. Buscamos, nas inferências transversais, localizar esse fenômeno como parte das transformações dos fenômenos religiosos no Brasil, acionadas e articuladas com observações das interações e fluxos em meios-dispositivos configurados institucionalmente.

Palavras-chave: Mediatização. Processos Mediáticos. Duplo Vínculo.

\begin{abstract}
This article results from an investigation referenced in two research processes. On the one hand, theoretical research on the relationship between mediatization and the problem of double bind, according to the approach of Watzlawick et al. (1972). This perspective is theoretically mobilized as a reference for communicational problematization within the scope of hypotheses about mediatization. On the other hand, this article condenses the results of a research on a media-religious phenomenon of the charismatic movement in Brazil, led by Father Robson de Oliveira, based on an observation field that comprises two television programs. These inferences refer to the participation of the faithful in a religious context, the configuration of the media circuit built and the constitution of Father Robson as a charismatic
\end{abstract}


leader, referenced in feedback processes. We seek, in the transversal inferences, to locate this phenomenon as part of the transformations of religious phenomena in Brazil, triggered and articulated with observations of the interactions and flows in institutionally configured meansdevices.

Key words: Mediatization. Mediatized Processes. Double Bind.

\begin{abstract}
Este artículo es resultado de una investigación basada en dos indagaciones. Por un lado, es una investigación teórica sobre las relaciones entre mediatización y la problemática del doble vínculo de acuerdo al abordaje de Watzlawick et alt. (1972). Por otro lado, el artículo sintetiza resultados de una investigación sobre un fenómeno mediático-religioso, el movimiento carismático de Brasil liderado por el Padre Robson de Olivera. Las inferencias presentadas en este en este artículo se refieren a la participación de los devotos en el contexto religioso, a la configuración del circuito mediático construido y a la constitución del Padre Robson como un líder carismático, referenciado en procesos retroalimentados. Buscamos, a través de inferencias transversales, localizar ese fenómeno como parte de las transformaciones de los fenómenos religiosos de Brasil, accionadas y articuladas con observaciones de las interacciones en flujos en medios-dispositivos configurados institucionalmente.
\end{abstract}

Palabras clave: Mediatización - procesos mediáticos - doble vínculo

\title{
1 INTRODUÇÃO
}

O conceito de mediatização aqui sugerido se diferencia de dois outros em vigor no 'norte': a) uma abordagem que consideramos ascendente - de construções sociais do midiático - e outra, descendente - dos meios à cultura que tende a ver mediatização como derivada da interação e acomodação dos diferentes campos às lógicas dos meios midiáticos. Chamamos a primeira de ascendente porque considera a mediatização como uma derivada, e não um processo específico, fundador de um deslocamento social que se sobrepõe às propensões das construções sociais de sentido viabilizadas pelos usos sociais dos meios; a segunda hipervaloriza os meios e suas lógicas, organizados ou institucionalizados, e não problematiza o contexto em que os meios midiáticos estão também imersos em um processo que se sobrepõe a eles, não só pelos usos sociais a jusante.

Entre os movimentos descendentes e ascendentes, acentuamos a transformação da matriz de interação mediática quando em redes. Nessas, o conceito de circulação é central, incluindo os processos de circulação ascendente e descendente, mas também o que ocorre no âmbito dos circuitos configurados pelas interações mediatizadas. Nessa perspectiva, o conceito de mediatização não é credor das linhagens de pesquisa baseadas em processos de produção e/ou recepção.

Entretanto, a pesquisa desenvolvida no Grupo de Pesquisa Midiatização e Processos Sociais se diferencia, sem negar a importância, de outras epistemologias que informam os 
estudos sobre mídia e religião. Por um lado, é diversa das pesquisas desenvolvidas a partir das teorias da recepção e da mediação em vigor nas epistemologias do sul. Citamos, aqui, em especial, referências utilizadas por Magali Cunha (2016). As hipóteses, proposições e métodos desenvolvidos pelo Grupo de Pesquisa se constituem num esforço investigativo que, nos últimos dez anos, procura se diferenciar das ofertas epistemológicas sugeridas pelas teorias da recepção e mediação. O centro da divergência está no conceito de circulação como outro lugar de observação relativamente ao que é sugerido pelo conceito de recepção.

Difere também do interessante trabalho desenvolvido por Luis Mauro Martino. Citamos em especial um artigo de Martino (2014), para identificar a especificidade do que propomos em nossas pesquisas. Martino parte de teorias para realizar um conjunto de inferências sobre as interações em rede entre indivíduos, atores e instituições em torno de formas religiosas no Brasil. A divergência está no ponto de partida. As teorias sociológicas, antropológicas, filosóficas e psicológicas são, em Martino, referências para argumentações dedutivas. Em nossas perspectivas, a validade de qualquer teoria sociológica, antropológica ou psicológica está condicionada a questões e proposições construídas no caso, decorrentes da análise da circulação.

É verdade que as inferências de Martino (2014) não são aqui estudadas. Martino investiga a zona de conflito, de luta pelo reconhecimento, entre religiosidades diversas. Nesse espaço, ocorre o que designamos de irrupções, analisáveis conforme a semiose mediatizada. O objeto deste artigo, entretanto, não tem como foco esses processos disruptivos. Aqui, trata-se, pelo contrário, de uma investigação em uma "zona regulada", construída nos processos de circulação, em que atores (devotos) e instituição (religiosa), de forma descendente e ascendente, interagem, resultando numa configuração específica que acentua a dimensão de duplo vínculo nas formas de religiosidade, conforme o tempo-espaço dos meios ofertados e usados socialmente.

\subsection{A interface: mediatização, comunicação e duplo vínculo}

Num dos capítulos de obra publicada no Brasil, Verón (2005) aborda a questão do duplo vínculo. É um artigo escrito com Carlos Sluzki, no qual os autores abordam a tensão entre dependência e independência, distinção entre self e não self, diferenciando os sintomas (patogenias) em histéricos, fóbicos e obsessivos. Sabe-se que a relação de Verón com a 
Escola de Palo Alto prossegue, inclusive quando aborda a circulação como relações entre sistemas.

O nosso interesse por essa abordagem, entretanto, não é ponto de partida, e sim de chegada da pesquisa aqui comunicada na forma de artigo, no qual apresentamos problematizações e inferências posteriores à pesquisa realizada no âmbito de dissertação de mestrado (CORTES, 2017).

Na pesquisa realizada, a semântica "duplo vínculo" surgiu como uma boa metáfora para a teorização das relações observadas que atores sociais estabelecem com dois espaços institucionais ou mais - conforme o caso abordado neste artigo (a instituição religiosa e a instituição especificamente mediática). Esse foco fica especialmente instigante quando essa multiplicação de vínculos institucionais está em relação com a presença, em uma de suas formas, do vínculo mediático.

Mas essa metaforização tem o seu ágio. É necessário responder a tensão com a Escola de Palo Alto. Portanto, é necessário ponderar. Mobilizamos, para isso, a Watzlawick et al. (1972). Primeiramente, ponderamos que as relações circulares entre emissor e receptor problematizadas por Watzlawick et al. (1972) como referência de comunicação mediatizada devem ser questionadas, em nossa perspectiva, pelas interposições dos meios materiais. Há algo aqui a ser decifrado. Os autores dizem assim: "nós queremos, pois, acentuar menos as relações do emissor (e do receptor) e do signo, e mais a relação que une emissor e receptor, quando essa está mediatizada pela comunicação" (WATZLAWICK et al., 1972, p. 17).

Sabemos que essa união (“que une"), na perspectiva dos autores, não é reificada. A investigação que realizam da patogênese através da observação das interações (em linguagens que chamam de analógicas e digitais) não nos permite dizer que, em suas perspectivas, uma comunicação seria um uno idílico. Mas há, aí, um problema que nos convoca ao contraditório. Ao considerar que o signo, seja ele dito analógico ou digital, permite o acesso à patogênese, há o risco de reduzir o signo a um lugar transparente e passivo na interação. Uma interação, portanto, vista sem considerar a semiose que é visitada pelas teorias do signo. Portanto, propomos que a interposição do signo transforma as interações, assim como o Coronavírus, um signo material, altera a natureza e a cultura.

Quando falamos em signo, estamos nos referindo a meios. Ou seja, o meio é, antes de tudo, um signo material construído pela espécie. O que a cultura chama de tecnologias são materializações da experiência mental e "retornam" às interações, interpondo-se nas interações entre os indivíduos da espécie, desses com a natureza e outros signos materiais 
construídos pela espécie. Ou seja, a mediatização não se reduz às interações entre emissores e receptores. Devem-se considerar os meios, signos materiais construídos pela espécie num processo histórico, na matriz que pensa as relações entre emissor e receptor. Se os meios são signos, signos que se interpõem, em suas materialidades, nas interações, agenciando-as, as interações entre emissor e receptor devem ser pensadas em uma matriz em que cada um desses polos agencia os outros dois.

Em nossa genealogia dos meios, interessam especialmente os meios modernos, que transitam dos meios de conteúdo (as variadas formas do impresso) aos de programação (rádio e televisão), de programação à indexação (da biblioteca às ferramentas de busca em www), de indexação aos de interação (Facebook, Instagram, WhatsApp, etc.), de interação aos algoritmos.

Os algoritmos, no contemporâneo, passam a constituir os meios dos meios agenciando os meios de conteúdo, programação, indexação e interação (FERREIRA, 2013). Isso é, o algoritmo é, antes de tudo, um signo - que articula regras e operações inferenciais agenciadoras de conteúdo, programações, interações e indexações. As dimensões técnicas (linguagens especificamente computacionais, por exemplo) e tecnológicas são subordinadas a essas regras e operações inferenciais - que são apropriações dos algoritmos da cultura e da natureza. Descobrir essas regras é um requisito para a crítica da comunicação pragmática na perspectiva da mediatização.

Essa perspectiva teórica vem sendo desenvolvida por nós nos últimos 15 anos (FERREIRA, 2007; 2013; 2016; 2017; 2018). A mediatização demanda a reflexão sobre as relações entre o processo de materialização (em meios) da experiência mental (segundo faz Verón (2014)), processos de comunicação (sobre os quais falamos acima) e sociais. Isso abre as explicações teóricas da mediatização a várias perspectivas epistemológicas, em interfaces que podem ser produtivas para a pesquisa empírica e para o diálogo com as teorias sociais e da linguagem.

Nessa perspectiva, os meios e dispositivos constituem a "infraestrutura" (modos de produção) dos processos de mediatização, e, por isso mesmo, destaca-se, em nossa perspectiva, a importância da pesquisa e reflexão sobre a genealogia dos meios, que são signos materiais (técnica e tecnologia) e podem ou não ser reconhecidos simbolicamente (constituindo-se em estruturas estruturadas e estruturantes das interações de forma mais permanente num período histórico - por exemplo, como rádio, televisão e cinema se constituíram em sistemas simbólicos de referência durante o século passado). 
Ao destacar esse lugar infraestrutural dos meios, pode-se questionar com a crítica (já canônica) que isso seria "midiacentrismo". Porém, há duas respostas, neste momento, a esse questionamento. A primeira é mais ou menos conhecida: o que dinamiza essa infraestrutura dos meios é a superestrutura (o que é analisável como circulação, comunicação ${ }^{1}$ e interação). A segunda está ancorada na matriz proposta: a interposição dos meios não "zera" as injunções dos processos comunicacionais e dos processos sociais, mas situa essas injunções em processos retroativos (e por isso uma teoria da mediatização não pode ser indiferente às teorias psico-sócio-antropológicas e da linguagem, mas busca uma nova inteligibilidade para essas heranças).

\section{2 Âcoras conceituais-metodológicas}

A interface epistemológica mediatização, comunicação e duplo vínculo nos convida a encaminhar o que apresentamos nessa seção intitulada âncoras conceituais-metodológicas. São apropriações das proposições de Watzlawick et al. (1972), considerando o campo de observação dos processos mediáticos na perspectiva da interface sugerida acima.

No plano da observação, a investigação dos processos mediáticos aqui sugerida não tem como objeto a interação de duas pessoas em clínicas. Esse é o objeto observado em Watzlawick et al. (1972). Nos processos midiáticos, temos sempre a abertura para a investigação de uma multiplicidade de atores, localizados em diversas posições institucionais, utilizando vários meios. Esse foco mais amplo afasta o objeto da análise clínica proposta pela psicologia, sem que isso signifique adesão a uma análise sociológica (pois não se trata de reflexão sobre as demografias sociais, acionada a partir das epistemologias da sociologia.

Essa perspectiva se aproxima da etnografia - onde o objeto são comportamentos de coletivos, mesmo quando esses não estão pré-desenhados institucionalmente ou são construídos nas interações, e só podem ser "vistos" pela análise ad hoc, relativamente às interações do presente. O objeto, portanto, refere-se às interações de atores com um determinado meio mediático (resultante de um sistema de produção a ser também analisado), e, por essa mediação, entre si (entre os atores localizados em diversas posições institucionais). Esta perspectiva está presente, por exemplo, em Ethnographie de l'exposition (VERÓN; LEVASSEUR, 1989), que analisamos em artigo recente (FERREIRA, 2020).

\footnotetext{
${ }^{1}$ Os processos de comunicação se referem àquilo que pode ser observado como interações sociais, incluindo as possibilidades das conversações: versões, perversões, inversões e todas as variações do verso nas interações entre dois ou mais interlocutores (atores, organizações e instituições).
} 
O segundo postulado, nessa proposta conceitual-metodológica, é o paradoxo da comunicação: os indivíduos, na posição de atores sociais, não podem não se comunicar; mas, ao se comunicar, enfrentam-se com os desafios do sintoma que se manifestam nas interações. Nesse sentido, o silêncio pode ser uma forma de sintoma do paradoxo - não se envolver com a interação para não se manifestar e ser desafiado perante a explicitação do sintoma.

Nossa proposta, aqui, adota essa perspectiva, mas com um deslocamento. Não se trata de analisar a patologia analisada pela psicologia social de Palo Alto (a histeria, a fobia e a obsessão (VERÓN, 2005), mas o duplo vínculo interacional que pode ser indiciado nas interações (incluindo o duplo vínculo subjacente à teoria do poder simbólico - comunicação é poder e união, conforme Bourdieu (1989)). As interações podem ser analisadas, portanto, como potencialmente reveladoras do duplo vínculo em diversos níveis: a impossibilidade de não se comunicar e o desafio da manifestação do sintoma; exercício do poder e demanda de autonomia do outro; o que une também hierarquiza.

O complexo dessa análise das interações em grupos e coletivos interpostas por meios diversos, com atores localizados em diversas posições institucionais, é que não se trata de estímulos, respostas e reforços de A e B, mutuamente condicionantes. Primeiramente, porque consideramos que a teoria comportamentalista, em suas diversas versões, baseadas na tríade estímulo-resposta-reforço, é insuficiente para dar conta do comportamento da espécie. A boa contribuição da Escola de Palo Alto (analisar essa tríade nas interações, como forma de capturar os impulsos do inconsciente - conforme problematização do inconsciente, em formas de histerias, obsessões, fobias e situações esquizofrênicas) também não é suficiente.

Em nossa perspectiva, é necessário agregar o processo de construção do social para além daquilo que herdamos (o inconsciente) e daquilo que fazemos no presente (interações aqui e agora, com estímulos, respostas e reforços). Para isso, é necessário pensar as interações como um trabalho do ego - no sentido da psicologia do ego, construtivista (que, em nossa abordagem, é referenciada em Piaget). Em outras palavras, consideramos que as epistemes individuais podem ser atualizadas nas interações, pelo trabalho cognitivo dos indivíduos, que assim pode mudar seus comportamentos, enquanto atores. $\mathrm{O}$ ego individual, nesse sentido, pode trabalhar para superar os paradoxos decorrentes do duplo vínculo, manifestas nas interações, considerando as interações acionadas pela tríade estímulos, respostas e reforços.

O objetivo desse programa de pesquisa em construção é oferecer à linhagem de pesquisa mediatização e processos sociais definições, explicações teóricas, conceitos, modelos relativos à tríade proposta para a compreensão da mediatização - relações entre 
meios materiais (e dispositivos), processos de comunicação e processos sociais. Em termos de processos psico-sócio-antropológicos, importa especialmente a crítica à revelação dos paradoxos enquanto processos históricos sociais recorrentes (conforme anotamos acima). Essa crítica não é só epistemológica. A própria sociedade responde a isso, através de críticas às incoerências decorrentes de vários vínculos. Aqui, a formulação de sistema social de resposta (BRAGA, 2006) pode ser produtiva.

Neste artigo em específico, entretanto, a meta é mais singela. O exercício metodológico se refere a identificar, num recorte de meios em constelação, no qual se observam interações, processos de retroação, um encadeamento de eventos interacionais, negativos ou positivos, que alimentam, conservam, produzem estabilidade, desequilíbrio qualitativos ou quantitativos, alimentados por reintroduções no "sistema recortado" de novas "informações" no circuito de interações, num processo de circularidade em fluxo, que capturam e mantêm atores, em diversas posições institucionais, em interação. É evidente que uma etnografia exaustiva, mesmo num circuito reduzido como o apresentado na parte de inferências sobre o empírico deste artigo, é de extrema complexidade (inclusive pela diversidade de formas-signos presentes - imagens, áudios, textos, corpos - nas interações, com toda a sua polifonia). O objeto, portanto, aqui se foca no desenho do circuito, como relações entre atores e lugares institucionais, sem alcançar esses detalhes da semiose.

Trata-se, portanto, de um desenho da maquete de lugares de visitação - construídos por uma instituição religiosa e visitados por seus seguidores - que, por analogia, pode ser vista nos desenhos de Verón (VERÓN; LEVASSEUR, 1989) sobre a exposição. Essa exposição é o meio material entre sistemas de produção e sistemas de recepção.

Neste artigo, procuramos desenhar as maquetes do sistema de produção, identificando fluxos interacionais mediatizados. A análise ampliada desses sistemas de produção e de recepção demandaria investigação com os produtores e receptores, com um roteiro de entrevistas já pontuado com a sequência de indícios, em interações encadeadas, que considerem a tríade estímulo-resposta-reforço, as manifestações de duplo vínculo e as operações sociocognitivas, a partir de atores presentes no circuito definido pela pequena constelação de meios. Esse roteiro questionaria inclusive os papéis dos atores no circuito analisado, conforme comportamentos - aceitáveis ou não pelos interagentes (incluindo relações entre 'líderes' institucionais, dependências psicossociais, autonomias, etc.), inclusive sob a forma de conflitos (tipo: quem é você para se comunicar assim?). 
Nesse sentido, este artigo está focado apenas em refletir sobre o sistema de produção materializado, apresentado na forma de maquetes (diagramas). Com esses limites decorrentes do objeto a ser visitado (os meios em pequena constelação), não se aborda também a questão das relações horizontais, minimização das diferenças, redução da rivalidade, busca de simetrias interacionais, etc. por parte dos atores envolvidos.

Finalizando essa seção relativa a apropriações da Escola de Palo Alto conforme proposições epistemológicas que apresentamos acima, o objetivo aqui é: a) análise dos meios em pequena constelação; b) compreendê-los para além de elementos independentes, e sim em relações e fluxos que direcionam os conteúdos ofertados; c) acionar o conceito de circuito como pequena constelação, portanto, analisável, quando materializada, enquanto meiodispositivo.

Esse circuito, quando em redes digitais, alimenta-se pelo paradoxo da comunicação (não é possível não se comunicar; mas se comunicar revela paradoxos), retroalimentado por ações individuais, mas essas sob o manto da atorização, o que nos permite falar em sistema dinâmico, impulsionado por interações contínuas, passíveis de análise, que manifestam ou não vínculos construídos, estimulados, reforçados, em seus conflitos e sintomas.

Com essa abordagem conceitual-metodológica, consideramos ser possível especificar, em casos de investigação, grandes processos que relacionamos à mediatização social. Esses processos agenciados podem se referir a mutações ${ }^{2}$ em diversos níveis:

a) Integração e diferenciação - os sistemas de produção materializados em meiosdispositivos integram indivíduos, que se apresentam como atores, num circuito (microconstelação), que se alimenta das interações. Nesse processo, observa-se diferenciação entre esses atores;

b) Conectividade, ubiquidade e onipresença - conectados, os indivíduos imersos nos circuitos passam a viver a onipresença, objetiva e subjetiva, tensionada pelos paradoxos da comunicação, incluindo o paradoxo de ser impossível não se comunicar e, perante os atos e em comunicação, manifestar sintomas psico-sócio-antropológicos relativos ao duplo vínculo que se revela nas interações;

c) Inovação, profecias e frustrações - as microconstelações nascem de promessas (utópicas ou não), mas suas realizações são referências de frustrações perante profecias;

\footnotetext{
${ }^{2}$ Parte dessas características foram acentuadas na conferência de Andreas Hepp no III Seminário Internacional de Pesquisas em Mediatização e Processos Sociais. A ampliação da escala é uma dimensão sempre acentuada por Verón.
} 
d) Aldeamento, ampliação da escala e reformulação dos territórios - o aldeamento em dispositivos configurados por meios em constelações produz territórios dentro do território e mudanças de escala das interações, possibilitando pontos de fuga em relação aos territórios físicos. Reformulam-se, portanto, de forma continua, os territórios anteriores.

e) Reconstrução do tempo e espaço - de forma subjacente, os indivíduos, na forma de atores, passamos a viver novos tempos e novos espaços sociais.

f) Adaptação, regulação, ritmos e irrupções - os processos adaptativos podem ser observados nas interações, em estímulos, respostas, reforços, patologias de poder (perversões), manifestando ou dissimulando paradoxos sociais, psicológicas e antropológicas, com direcionamentos sociocognitivos que podem se sobrepor aos limites inclusive das regulações e ritmos da microconstelação. Não só eventualmente, irrupções psico-sócio-antropológicas podem emergir na constelação. Ou, eventualmente, a capacidade adaptativa equaciona novas soluções no âmbito do circuito.

\section{O CASO SINGULAR EM ANÁLISE}

O caso singular abordado neste artigo é, por um lado, o desenho da microconstelação; por outro, o duplo vínculo com instituição religiosa e especificamente mediática. Falamos especificamente pois consideramos que a instituição religiosa é também mediática, mas seus fins não se confundem com as apropriações dos meios modernos, construídos como referência de um espaço público laico, nos quais o compromisso é a promessa de distanciamento em relação a todas as instituições herdadas e construídas pelas mutações correlatas ao capitalismo e, também, em relação ao espaço privado.

Empiricamente, entretanto, essa formulação, que é teórica, demanda mediações de investigações que tenham como objeto casos construídos. O objeto específico da pesquisa empírica aqui apresentada são as novas formas de regulação em processos midiáticos. Questiona-se como essas reconfigurações nesses processos acionam, ao mesmo tempo, mutações religiosas, em específico das interações entre os especialistas (os padres) e seus públicos (os leigos). Especificamente, abordam-se as configurações do meio-Igreja no contexto das interações entre atores e instituição, em redes digitais.

O campo de observação compreende dois dos programas agenciados pela AFIPE (Associação Filhos do Pai Eterno); o primeiro é o Programa Pai Eterno e o segundo o 
Programa Novena dos Filhos do Pai Eterno. Mesmo sendo apresentados em sequência na programação da televisão e geridos pela AFIPE, ambos possuem distinções grandes na forma como utilizam os meios para circulação e interação com os devotos. Tais características serão analisadas aqui separadamente. No fim desta distinção, buscamos correlacionar o que se verifica no conjunto dos fluxos midiáticos acionados e controlados tentativamente) pela AFIPE.

O período selecionado para a coleta é o de 06/11/2015 até 23/11/2015, momento este em que foram realizados dois ciclos das "Novenas Internacionais", época em que o programa foi gravado fora do país. No caso específico, as gravações foram realizadas na Terra Santa em Israel, local onde os cristãos acreditam que Jesus Cristo nasceu e viveu.

\subsection{A religião, do templo e da televisão às redes digitais}

O Brasil abriga hoje importantes canais de televisão com inspiração de movimentos de entidades católicas, como é o caso da Rede Vida de Televisão, TV Aparecida e TV Canção Nova. Isso num cenário em que, mesmo sendo o Brasil um país predominantemente católico, o número de seguidores das igrejas neopentecostais cresceu muito ao longo da última década. Credita-se esses movimentos aos usos de meios de comunicação, pois tiveram uma adaptação mais rápida à televisão e aos meios em redes digitais. Esses casos são objeto de estudo do Grupo de Pesquisa Mediatização e Processos Sociais, que nos últimos anos desenvolveu teses e dissertações sobre a IURD (Igreja Universal do Reino de Deus) e a Igreja Mundial do Poder de Deus, que disputam, com a Igreja Internacional da Graça de Deus, a hegemonia no campo neopentecostal ${ }^{3}$. Seus pastores são designados como os mais ricos do Brasil ${ }^{4}$.

Neste contexto, a Igreja Católica vive no momento um dos maiores ápices de "imersão em mídias" no Brasil. Um dos grandes responsáveis por este avanço é o líder da Associação Filhos do Pai Eterno (AFIPE), Padre Robson de Oliveira ${ }^{5}$. Presente na programação da Rede Vida de Televisão, o líder religioso realiza uma intensa atividade religiosa através da TV, redes digitais e aplicativos móveis. Acionando esses meios, a Igreja Católica passa a ter um

\footnotetext{
${ }^{3}$ Fonte: http://www.ihu.unisinos.br/159-noticias/entrevistas/569799-lideres-das-tres-principais-igrejasneopentecostais-travam-armagedom-mediatico-entrevista-especial-com-alexandre-dresch-bandeira. Acesso em: 01 set. 2020.

${ }^{4}$ Fonte: http://www.ihu.unisinos.br/171-noticias-2013/517059-com-fortuna-de-r-2-bilhoes-edir-macedo-e-opastor-evangelico-mais-rico-do-brasil-diz-revista. Acesso em: 01 set. 2020.

${ }^{5}$ Fonte: http://www.paieterno.com.br/site/. Acesso em: 01 set. 2020.
} 
representante que consegue atingir quase 4 milhões de usuários ${ }^{6}$ diariamente através das redes digitais.

O Programa Pai Eterno vai ao ar de segunda a sexta-feira às $7 \mathrm{~h} 45 \mathrm{~min}$. Ele é mantido pela AFIPE, Associação dos Filhos do Pai Eterno, criada em 2004 pelo Padre Robson de Oliveira com o intuito de levantar fundos para a evangelização através dos meios de comunicação, além de ajudar na construção de um novo santuário.

A Associação, que passou a transmitir missas realizadas no Santuário Basílica do Divino Pai Eterno em Trindade, Goiás, em 2004, desde então se transformou e, em 2013, além da transmissão das missas diárias, inseriu o Programa Novenas dos Filhos do Pai Eterno, apresentado por Padre Robson em dois horários diários. O Programa Novena é um espaço de orações e contato dos devotos com o líder religioso. A primeira transmissão do Programa Pai Eterno foi ao ar no dia $1^{\circ}$ de janeiro de 2013. Em uma entrevista dada uma jornalista na edição de lançamento do programa, o Padre Robson de Oliveira coloca o espaço na Rede Vida como uma maneira de prestar contas do que está sendo feito com as contribuições gerenciadas pela AFIPE.

O programa é apresentado pela jornalista e cantora gospel Talitta Di Martino e traz matérias sobre os eventos promovidos pela AFIPE, o desenho animado Turminha do Pai Eterno, participação e testemunhos de devotos em missas e nas redes sociais, além de mostrar o dia a dia do Padre Robson de Oliveira.

\subsection{O fluxo desenhado pelas interações em torno do Programa Pai Eterno}

Nosso primeiro movimento de observação considera o conjunto do fluxo de mensagens de participação em meios diversos em redes digitais, acionado em torno do Programa Pai Eterno, na televisão. A partir desse fluxo, desenhamos o diagrama proposto abaixo (Figura 1), onde é possível visualizar os meios em rede, que são configurados pelas interações, constituindo um circuito mediático e de comunicação deste Programa:

\footnotetext{
${ }^{6}$ Fonte: https://www.facebook.com/PadreRobsonOliveira/. Acesso em: 01 set. 2020.
} 


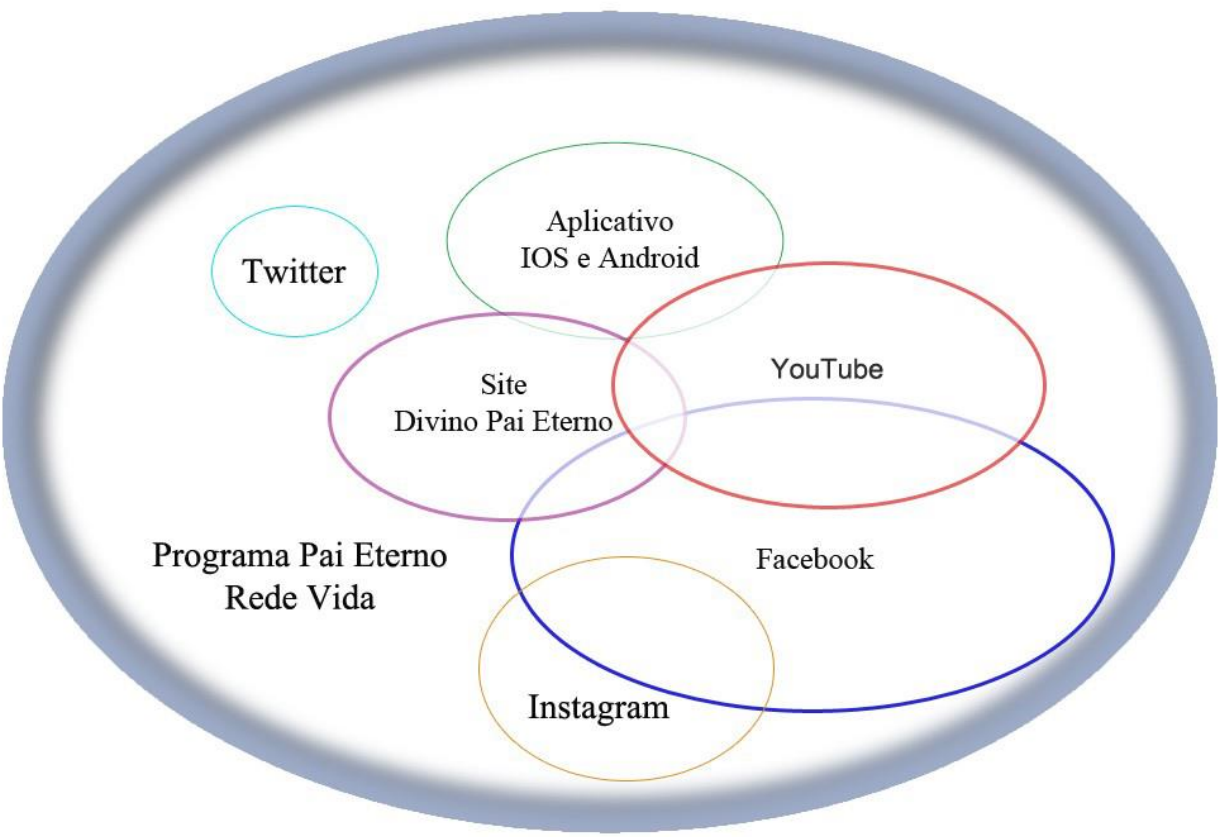

Figura 1 - Eixos instituídos pelas Diretrizes Curriculares Nacionais do Curso de Administração Fonte: Elaborado pelo autor (2020)

Ao examinarmos os fluxos acionados pelo programa televisivo Pai Eterno, organizamos a forma como são dispostos frente aos usos e cruzamentos do processo em circulação no complexo fluxo de conteúdos. O quadro televisivo "Mural dos Devotos" é abastecido por meio de mensagens e fotos apropriadas das redes sociais Facebook e Instagram, e de envios por e-mail ou carta postal. No quadro "Mãos à Obra", o conteúdo produzido possui uma variação que compreende desde a participação do público em entrevistas, depoimentos ou reportagens até a apropriação de mensagens em redes sociais ou enviadas diretamente. O espaço no programa chamado "Rumo à Casa do Pai" retrata a experiência de viagem dos devotos a caminho da visita ao Santuário. No quadro são utilizados vídeos amadores enviados pelo público que grava o trajeto e encaminha via e-mail ou carta. Os quadros "Palavras de Fé" e "Filhos Peregrinos" utilizam o devoto na criação de conteúdo televisivo. No caso do "Palavras de Fé", os devotos são utilizados contando depoimentos de graças alcançadas. No quadro "Filhos Peregrinos" são reunidas reportagens com devotos em viagem que visitam as dependências da Igreja ou Santuário Basílica.

No quadro a seguir, são destacados os quadros internos do Programa Pai Eterno e os tipos de utilização do discurso do devoto em diversas formas: envio de conteúdo (vídeos, imagens), que sempre é acompanhado da leitura de e-mail ou carta pela apresentadora Talitta 
Di Martino; na segunda coluna da tabela a seguir são dispostos os quadros do programa que aproveitam mensagem ou imagem publicada em redes sociais; por fim, a terceira guia exibe os quadros que usam o devoto em material produzido (entrevista, devoto como repórter, depoimento, em apresentação de ações).

\begin{tabular}{|c|c|c|c|}
\hline Quadros do Programa & Envio de Conteúdo & $\begin{array}{l}\text { Apropriado de Redes } \\
\text { Sociais }\end{array}$ & Material Produzido \\
\hline Mural dos Devotos & $\mathrm{X}$ & $\mathrm{X}$ & - \\
\hline Mãos à Obra & - & $\mathrm{X}$ & $\mathrm{X}$ \\
\hline Rumo à Casa do Pai & $\mathrm{X}$ & - & - \\
\hline Palavras de Fé & - & - & $\mathrm{X}$ \\
\hline Filhos Peregrinos & - & - & $X$ \\
\hline
\end{tabular}

Quadro 1 - Meios de produção e de recepção - distribuição no Programa Pai Eterno Fonte: Cortes (2017, p. 50).

\subsection{Ativismo religioso: participe!}

Um conjunto de ações discursivas mobilizam os devotos a participar da evangelização, através de várias formas, em atividades explicitadas nas redes digitais. Listamos os principais indícios abaixo.

- Vídeos ficcionais que trazem mensagens/roteiros para o espectador acreditar no Pai Eterno, com o propósito de mobilizar crentes para evangelizar descrentes. Estes indícios podem ser encontrados em matérias de evangelização no Youtube, Facebook e no site ${ }^{7}$;

- Os vídeos trazem explicitamente o pedido de compartilhamento com amigos e familiares no Facebook das mensagens e página do "pastor" Padre Robson. Afirmam que isto é uma maneira de evangelizar, fazer uma boa ação. O termo utilizado pelo Padre Robson é "evangelizar nas redes sociais"

- Na página no Facebook e Instagram, Pai Eterno pede que devotos compartilhem a Hashtag (\#eunaromaria) com imagens na Romaria9;

- O texto de chamada na TV e nas redes sociais diz assim: Sua participação poderá ser veiculada no \#ProgramaPaiEterno ${ }^{10}$;

\footnotetext{
${ }^{7}$ Fonte: http://www.paieterno.com.br/site/?s=videos\&x=0\&y=0. Acesso em: 01 set. 2020.

${ }^{8}$ Fonte: http://www.paieterno.com.br/site/?s=evangelizar+nas+redes+sociais $\& x=0 \& y=0$. Acesso em: 01 set. 2020.

9 Para compreender a Romaria, suas origens e finalidades, ver: https://www.paieterno.com.br/historia/.

${ }^{10}$ https://www.facebook.com/PadreRobsonOliveira/photos/pb.188632391196891.-

2207520000.1508054396./1614169745309808/?type=3. Acesso em: 01 set. 2020.
} 
- O programa Pai Eterno pede que devotos compartilhem a Hashtag no Facebook com imagens de mensagens de apoio à obra de construção do novo Santuário do Divino Pai Eterno ${ }^{11}$;

- Quadro semanal do Programa Divino Pai Eterno, onde são divulgadas mensagens de interações oriundas da página do Facebook do Padre Robson. As matérias correspondentes podem ser vistas no Mural de Devotos - TV, Facebook e Twitter ${ }^{12}$;

- Uso do devoto para depoimentos sobre a crença, intermediada pelo Padre Robson de Oliveira/Programa de TV, e seus efeitos de fé e milagres ${ }^{13}$;

- Os aplicativos móveis trazem nas áreas Novenas e Santa Missa a transmissão de vídeos em streaming ou on demand dos programas televisivos Homilias (Santa Missa) e Novenas (Novenas dos Filhos do Pai Eterno, Novena do Perpétuo Socorro e Santo Terço);

- Pedidos de orações e velas virtuais. A equipe do Divino Pai Eterno se compromete a levar as orações até grandes missas televisionadas periodicamente ${ }^{14}$.

\subsection{Configuração do circuito mediático do Programa Novena dos Filhos do Pai Eterno}

Também como parte das inferências indutivas, listamos um conjunto de fluxos observados entre os meios mobilizados (campo de observação). Neste momento da investigação, a abordagem é de mapeamento dos meios e dos tipos de processos interacionais envolvidos.

O propósito da primeira observação é o de descobrir que meios fazem parte da configuração do programa televisivo Novena dos Filhos do Pai Eterno. Constatou-se que seis meios fazem parte deste processo: e-mail e/ou carta (Caixa Postal), TV, site oficial da AFIPE, aplicativo móvel e carta do Padre. A leitura feita pelo Padre Robson de testemunhos enviados é o único processo interacional exposto diretamente no meio televisivo. Não há entrevistas e depoimentos no formato de reportagens. O mediador é o Padre Robson.

\footnotetext{
${ }^{11}$ Fonte:

http://www.paieterno.com.br/site/?s=constru\%C3\%A7\%C3\%A3o+do+novo+Santu\%C3\%A1rio+do+Divino+Pa $\mathrm{i}+$ Eterno\&x=16\&y=20. Acesso em: 01 set. 2020.

$12 \mathrm{http}: / / \mathrm{www}$. paieterno.com.br/site/?s=mural+de+devotos $\& \mathrm{x}=0 \& \mathrm{y}=0$. Acesso em: 01 set. 2020.

$13 \mathrm{http}: / / \mathrm{www}$. paieterno.com.br/site/?s=depoimentos\&x=0\&y=0. Acesso em: 01 set. 2020.

${ }^{14} \mathrm{http} / / /$ www.paieterno.com.br/site/?s=ora\%C3\%A7\%C3\%B5es\&x=0\&y=0. Acesso em: 01 set. 2020.
} 
Este lugar de mediador do Padre Robson e do meio televisivo não esgota, entretanto, os fluxos observados.

Ao considerar a criação do próximo quadro foi organizada a origem da distribuição das mensagens enviadas pelos devotos por um meio. Elas são integradas a outros meios em diferentes formatos, configurando o que chamamos de circuitos midiáticos - considerando-se, agora, o Programa Novena.

\begin{tabular}{|c|c|c|c|c|c|}
\hline $\begin{array}{l}\text { Meio } \\
\text { receptor } \rightarrow\end{array}$ & TV & Site & Aplicativo & Carta do Padre & $\begin{array}{l}\text { E-mail } \\
\text { Carta }\end{array}$ \\
\hline \multicolumn{6}{|l|}{$\begin{array}{l}\text { Meio } \\
\text { produção } \downarrow\end{array}$} \\
\hline TV & - & - & - & - & - \\
\hline Site & $\mathrm{X}$ & $\mathrm{X}$ & $\mathrm{X}$ & $\mathrm{X}$ & - \\
\hline Aplicativo & $X$ & $\mathrm{X}$ & $X$ & $\mathrm{X}$ & - \\
\hline Carta Padre & - & - & - & - & - \\
\hline E-mail/Carta & $X$ & $\mathrm{X}$ & $\mathrm{X}$ & $\mathrm{X}$ & - \\
\hline
\end{tabular}

Quadro 2 - Meios de produção e de recepção - distribuição no Programa Novena Fonte: Cortes (2017, p. 41).

$\mathrm{O}$ quadro 2 traz a origem de mensagens de devotos e por quais meios ela acaba ressurgindo foi criada na investigação dos meios que constituem o circuito construído em torno do programa televisivo. Para isso, observamos os meios e suas especificidades, incluindo aqueles no qual é criado um material televisivo produzido pela equipe de comunicação com a participação do público. Os devotos são inscritos no programa através das seguintes ações: a) por meio de entrevistas; b) apresentação de material enviado (como os testemunhos de curas); c) através de usos de publicações de devotos em redes sociais. Ou seja, a programação faz uso sistemático dos relatos, narrativas e falas dos devotos.

Traçando essa perspectiva, destacamos esse entrelaçamento entre os meios como uma configuração de um circuito comunicacional mediatizado. Verificamos então as prováveis disposições que as mensagens ocupam aí, em relação aos meios utilizados.

A TV surge como meio institucionalizado, que marca o trânsito do circuito através de uma mensagem do devoto nascida de uma entrevista, relato ou algo semelhante. Já a estrutura do site é meio de memória e, também, de contextualização do programa televisivo. Publica testemunhos escolhidos, já lidos anteriormente pelo Padre na emissora. O aplicativo móvel, por sua vez, tem igualmente a função de publicação de testemunhos. A carta do padre é enviada aos devotos associados e é publicada no espaço de interface com os testemunhos enviados pelos devotos. A partir desses indícios, inferimos que as mensagens vindas por email ou cartas são fonte de agendamento da programação. 
Verificamos também a incidência dos mesmos testemunhos no site-aplicativo através da ferramenta de pesquisa por testemunho ${ }^{15}$ com o uso de palavras-chave, no caso os nomes dos atores que enviaram os testemunhos lidos pelo Padre no período. Nossa análise permitiu constatar que há testemunhos publicados no site-aplicativo que são lidos pelo Padre no programa televisivo. Isso traz à tona um movimento em que os meios em redes digitais são formas de captura e/ou passagem para posterior institucionalização ampliada no programa da TV.

Intuímos que as cartas enviadas pelo Padre são marcas importantes do trânsito em análise. São as promessas aos devotos. Para analisar as cartas mensais do Padre, recorremos a uma associada que nos forneceu acesso às cartas que ela recebeu no período de janeiro de 2013 até julho de 2015. A partir desta data, o pesquisador coautor se associou à AFIPE para receber as cartas durante o período de realização da pesquisa. Na área "Testemunhos" das cartas enviadas pelo Padre aos associados são também publicadas mensagens enviadas pelos devotos. No espaço há uma espécie de convocação, estimulando o envio contínuo de novos testemunhos através de e-mail, carta (caixa postal), além do endereço do site da AFIPE. É um processo de interação, de comunicação.

Observamos que os relatos enviados por correspondência passam pelo processo de seleção e distribuição, conforme o discurso do Padre. Isso é, se o devoto utilizou e-mail ou carta, isso se observa quando é reportado no discurso do Padre, antes ou depois de ele ler as mensagens de testemunhos no programa televisivo. Como a atração televisiva é disponibilizada no site-aplicativo através do formato de vídeo, é possível ter acesso às mensagens enviadas por e-mail ou carta igualmente neste meio.

A partir dos vários fluxos identificamos um esquema geral em que lugares de produção se direcionam (direção das setas) a lugares de recepção, que, por sua vez, são lugares de produção mediática. Ilustramos esse processo na figura 2, a seguir:

${ }^{15}$ Fonte: http://www.paieterno.com.br/site/oracao/testemunhos/. Acesso em: 01 set. 2020. 

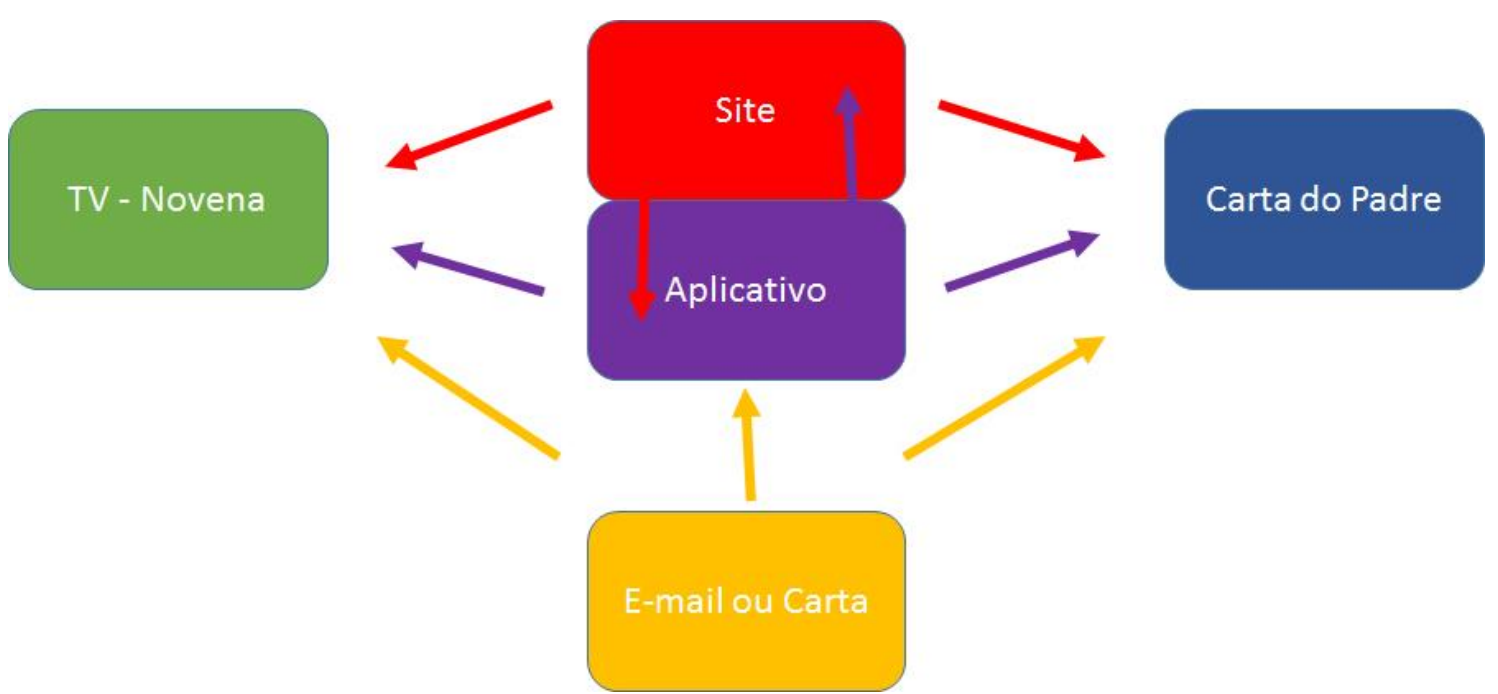

Figura 2 - Diagrama geral dos fluxos entre os meios Fonte: Cortes (2017, p. 35).

\subsection{Do vigário a líder religioso}

Quando abordamos a possível centralidade do líder religioso, no caso o Padre Robson, podemos observar que há uma concentração na incidência de conteúdos nos quais o Padre é colocado como referência simbólica, ou seja, lógicas de figuração e personificação da relação Pai Eterno-Padre Robson. A concentração na disseminação de representações mediáticas onde o Padre está em destaque ou em fusão com o religioso é observada através das redes sociais ${ }^{16}$.

Sempre que os endereços de páginas de redes sociais como Facebook ${ }^{17}$ e Instagram $^{18}$ são divulgados nos programas televisivos, vídeos da AFIPE e site do Santuário, há uma remissão para páginas e perfis do Padre Robson de Oliveira. No meio Facebook, não só consta o nome do Padre, mas ele contém igualmente fotos do líder religioso e figuras do novo Santuário que está sendo construído, em vez do ícone do Divino Pai Eterno, como pode ser observado nas figuras a seguir.

\footnotetext{
${ }^{16}$ Adotamos, aqui, a referência clássica de Peirce: o ícone (figuras), o primeiro; o índice, o segundo; o símbolo, o terceiro.

${ }^{17}$ Página do Padre Robson/AFIPE - Facebook: www.facebook.com/PadreRobsonOliveira/.

${ }^{18}$ Página do Padre Robson/AFIPE - Instagram: www.instagram.com/padrerobsonoliveira/.
} 

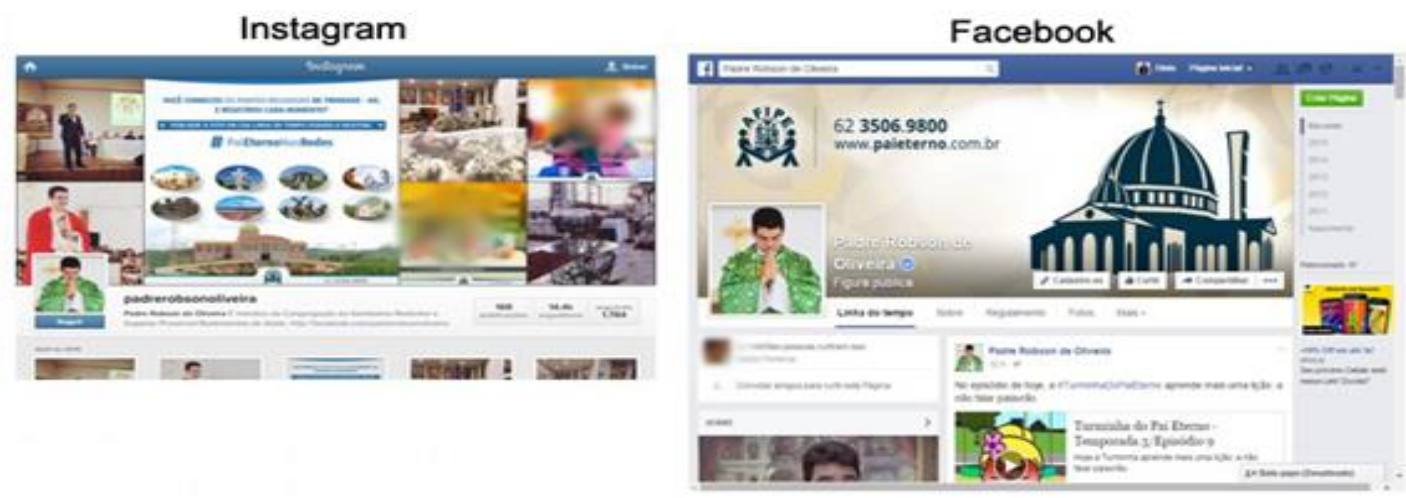

Figura 3 - Imagens capturadas das páginas de redes sociais gerenciadas pela AFIPE

A página na rede Facebook recebe atualizações constantes com os materiais da AFIPE e reproduções de conteúdos televisivos. Em algumas ocasiões, recebe mensagens de produção pessoal do Padre que interage repetidamente com seus seguidores nos comentários. Portanto, observando a forma como é disposta a figuração do Padre na rede, é possível perceber como são conduzidas as práticas que convergem num processo tentativo de estabelecimento da centralidade do líder, frente às operações da associação e da propagação de que ele é uma figura representativa (o vigário) para os devotos da crença religiosa (Igreja). Dessa forma, reforça-se constantemente a importância da imagem do Padre como uma figura pública de poder descendente frente aos devotos que o seguem na rede social digital.

Numa relação sistemática de conteúdos produzidos pela equipe de jornalistas da assessoria de comunicação da AFIPE, as redes digitais são abastecidas com materiais que fazem a divulgação das ações da associação religiosa, da devoção de devotos pela fé, mas, principalmente, da rotina do Padre em contato com os seus seguidores na Igreja ou em visitas.

O programa televisivo Pai Eterno traz como uma das suas abordagens o acompanhamento em autorreferência às atividades e às viagens para missas e shows que o Padre realiza. O líder religioso está presente nos horários da programação da AFIPE na TV, apresentando a Missa do Divino Pai Eterno, a Novena dos Filhos do Pai Eterno, a Novena do Perpétuo Socorro e o Terço do Divino Pai Eterno. Isso inclui a reprodução em formato de vídeo na rede Facebook do programa televisivo Pai Eterno é reproduzido. O líder, nesse sentido, é um ícone midiático que transita, ubíquo, que configura tentativamente um símbolo.

A rede Facebook permite que seus usuários ativos utilizem espaços de troca de mensagens públicas, seja em uma publicação para a sua rede particular de mensagens ou em comentários, nos quais os autores estão inscritos como membros participantes. Neste meio, são dispostas interações abertas com os devotos, que, no caso em estudo, são os devotos 
seguidores do Padre Robson/AFIPE. Evidencia-se aí a troca de dádivas (FERREIRA, 2016): da instituição, a cura; do interagente, a participação e o reconhecimento.

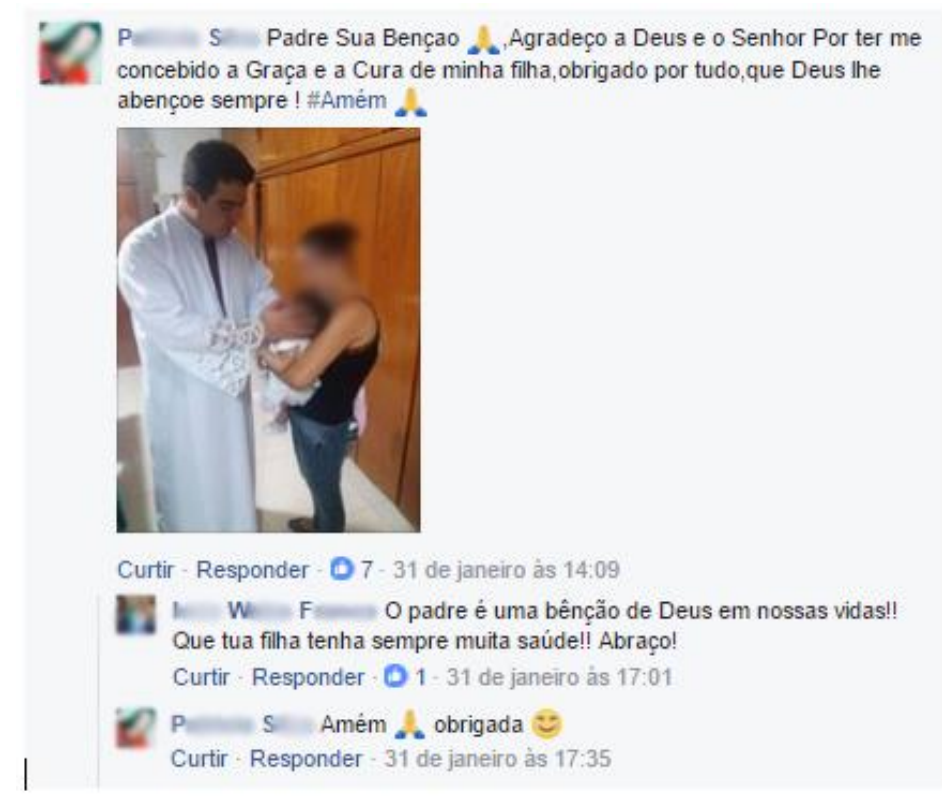

Figura 4 - Padre interage com devota na rede social Facebook ${ }^{19}$

Ou seja, a representação do Padre no meio Facebook não se limita à reprodução dos programas televisivos. O espaço é utilizado para mostrar, em imagens, o Padre em contato com os devotos, a adoração em torno da sua figura de líder, e, ao mesmo tempo, no Mural dos Devotos na página do Facebook são publicadas as fotos dos devotos presentes em missas do Padre. Evidencia-se, aqui, o quadro identificado no caso: dádivas institucionais e dos devotos cruzadas com o duplo reconhecimento, religioso e midiático.

${ }^{19}$ Fonte: www.facebook.com/ PadreRobsonOliveira/. 


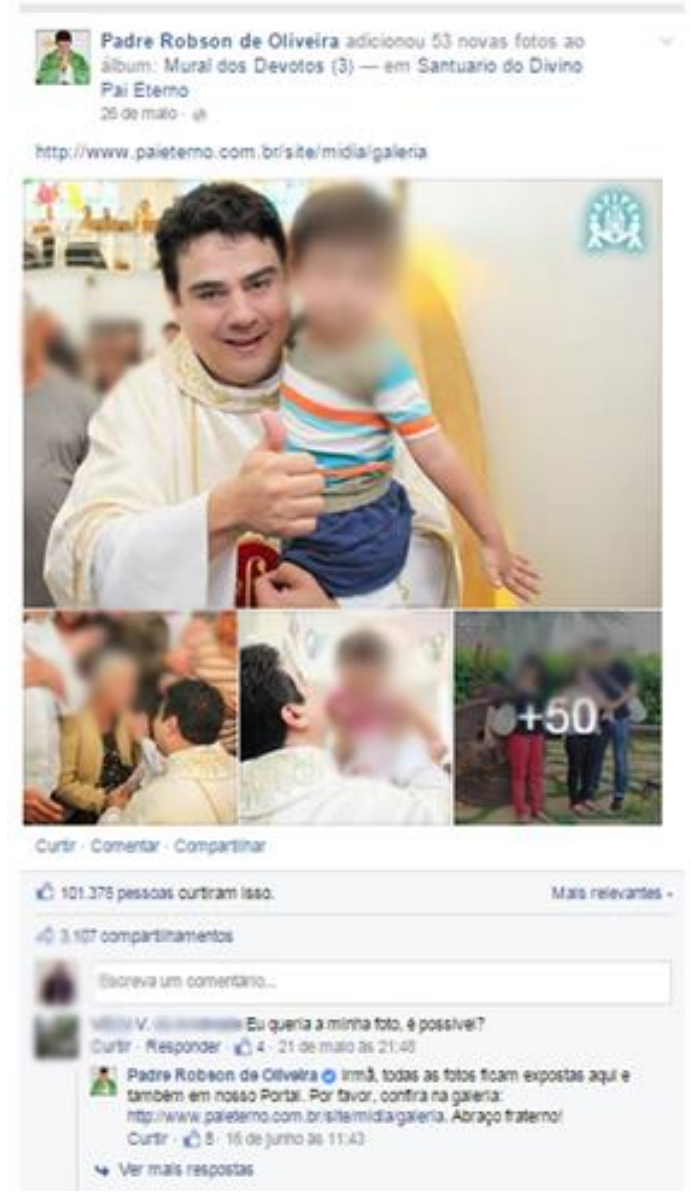

Figura 5 - Print Screen capturado da página do Facebook do Divino Pai Eterno-Padre Robson em 21/02/2016

A participação do Padre na televisão com abrangência nacional e nas redes sociais com quase 4 milhões de seguidores faz de Robson de Oliveira uma personalidade com seguidores que o idolatram. A palavra idolatria pode parecer forte; afinal, estamos falando aqui de um Padre que representa um segmento interno da Igreja Católica. Porém, a imagem de Robson é convertida por seguidores em alguém que pode interceder por eles, ou alguém que trouxe às suas vidas alguma dádiva, por apresentar a doutrina religiosa do Divino Pai Eterno em novenas, missas, ou até mesmo como um conselheiro, motivador.

\subsection{Retroalimentação nos processos sociomidiáticos}

Esse processo midiático se manifesta enquanto processo social. O Padre já esteve em diversos lugares do Brasil fazendo suas missas-show. Comerciantes acabam adotando sua imagem para vender itens como o seu CD de oração, camisetas e canecas com a imagem do Padre impressa. 


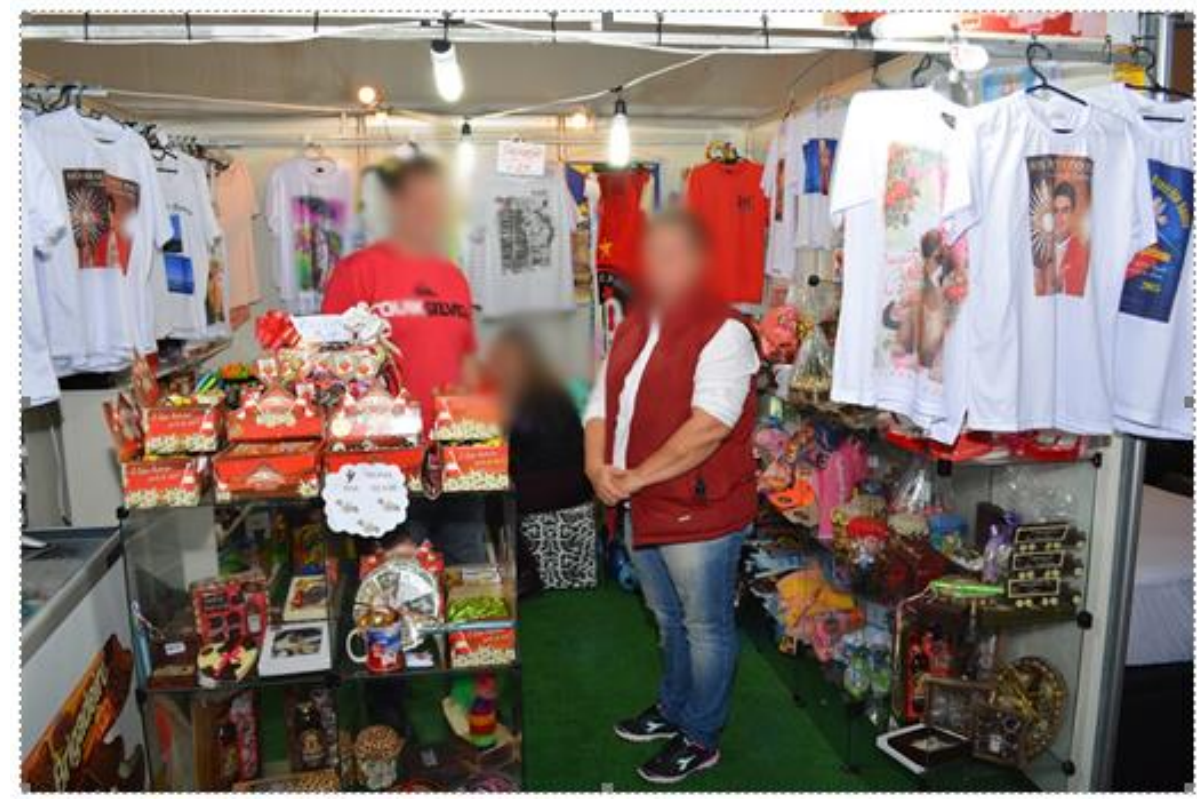

Figura 6 - Imagem da Festa do Divino em Guaratuba-PR. Crédito: Correio do Litoral ${ }^{20}$

Dentro da rede Facebook, seguidores do Padre demonstram seu apreço ao líder religioso, ensaiando um ativismo de fã. Alguns deixam apenas comentários de apoio na página oficial do Padre, que eventualmente são selecionados e exibidos na TV. Outros seguidores do Padre entram numa imersão no processo de divulgação da AFIPE, da religiosidade, evangelizando junto ao Divino Pai Eterno. Alguns vão ainda além, utilizam a rede social para manifestar seu gosto (AMARAL, 2014) por determinada religião ou afirmar que são fãs do Padre e pedem ajuda para levar adiante a mensagem proposta pelo Padre.

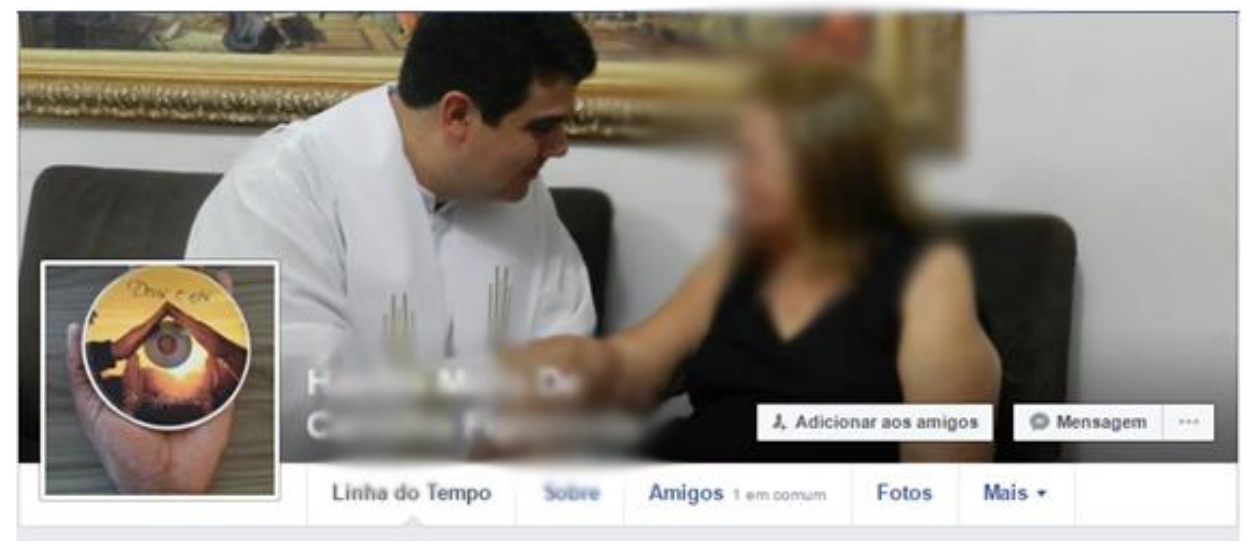

Figura 7 - Imagem de perfil de devota na rede social Facebook ${ }^{21}$

\footnotetext{
${ }^{20}$ Fonte: https://correiodolitoral.com/7053/festa-do-divino-vai-ate-o-domingo-19-em-guaratuba Acesso em: 01 set. 2020.

${ }^{21}$ As informações utilizadas foram coletadas de perfis de devotos seguidores que interagiram com o perfil do Padre Robson de Oliveira e redes sociais da AFIPE através de publicações da mesma durante o período de
} 
Na figura acima, a devota acaba por compartilhar para a sua rede de seguidores publicações relacionadas à AFIPE, pedindo e convocando seus seguidores a participar dela utilizando um slogan da AFIPE nos seus programas televisivos: "Venha ser feliz nessa família de amor" (Programa Pai Eterno e Programa Novena dos Filhos do Pai Eterno).

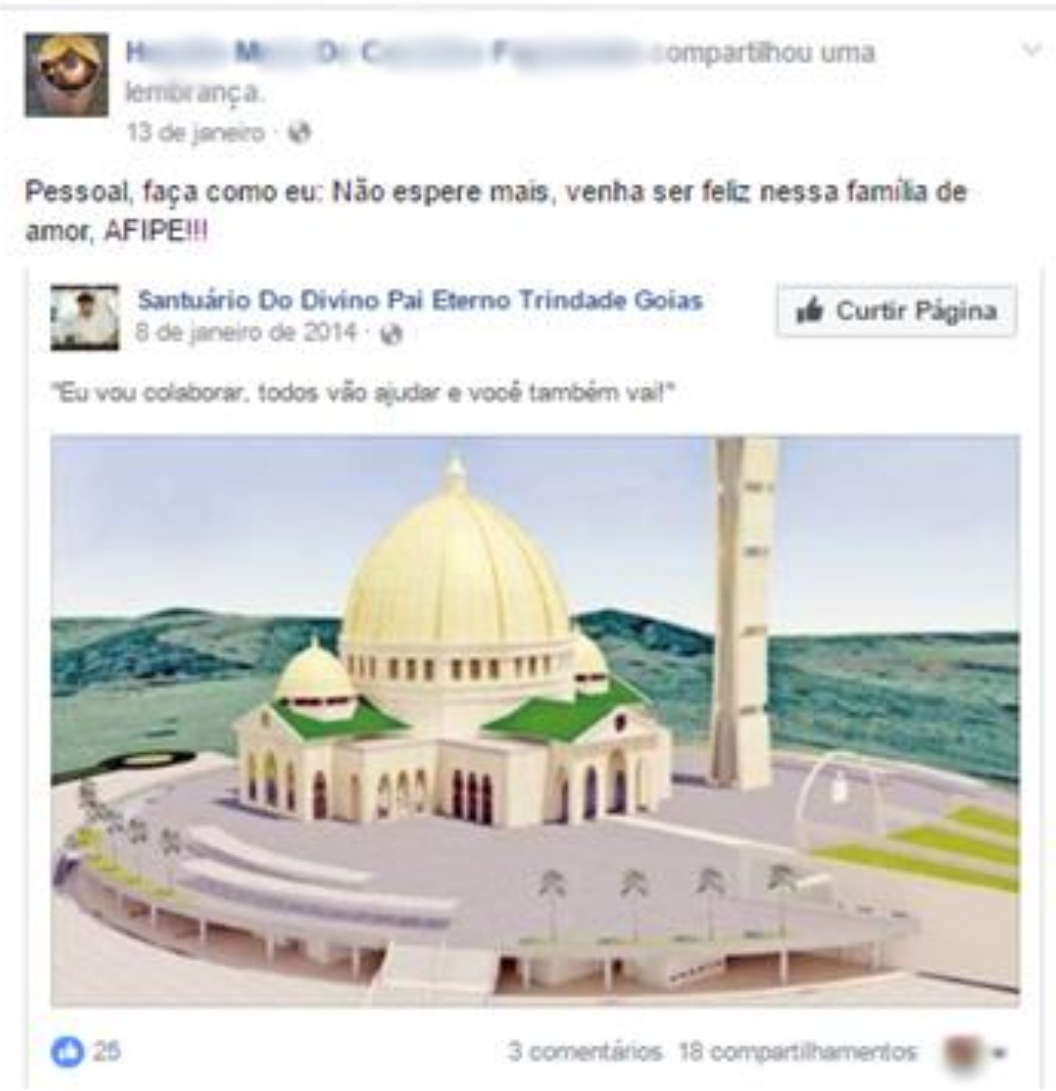

Figura 8 - Imagem de perfil de devota na rede social Facebook

A mescla entre a imagem do Padre, da AFIPE e do Divino Pai Eterno é observada nesta coleta realizada também no perfil de uma seguidora do Padre. A convergência da representação do Padre como ícone que se apropria da simbólica Santíssima Trindade é vista no agradecimento feito pela devota na rede social que é direcionado para o Divino Pai Eterno. O que se destaca são as imagens do Padre Robson de Oliveira junto com a representação simbólica religiosa da Santíssima Trindade. 


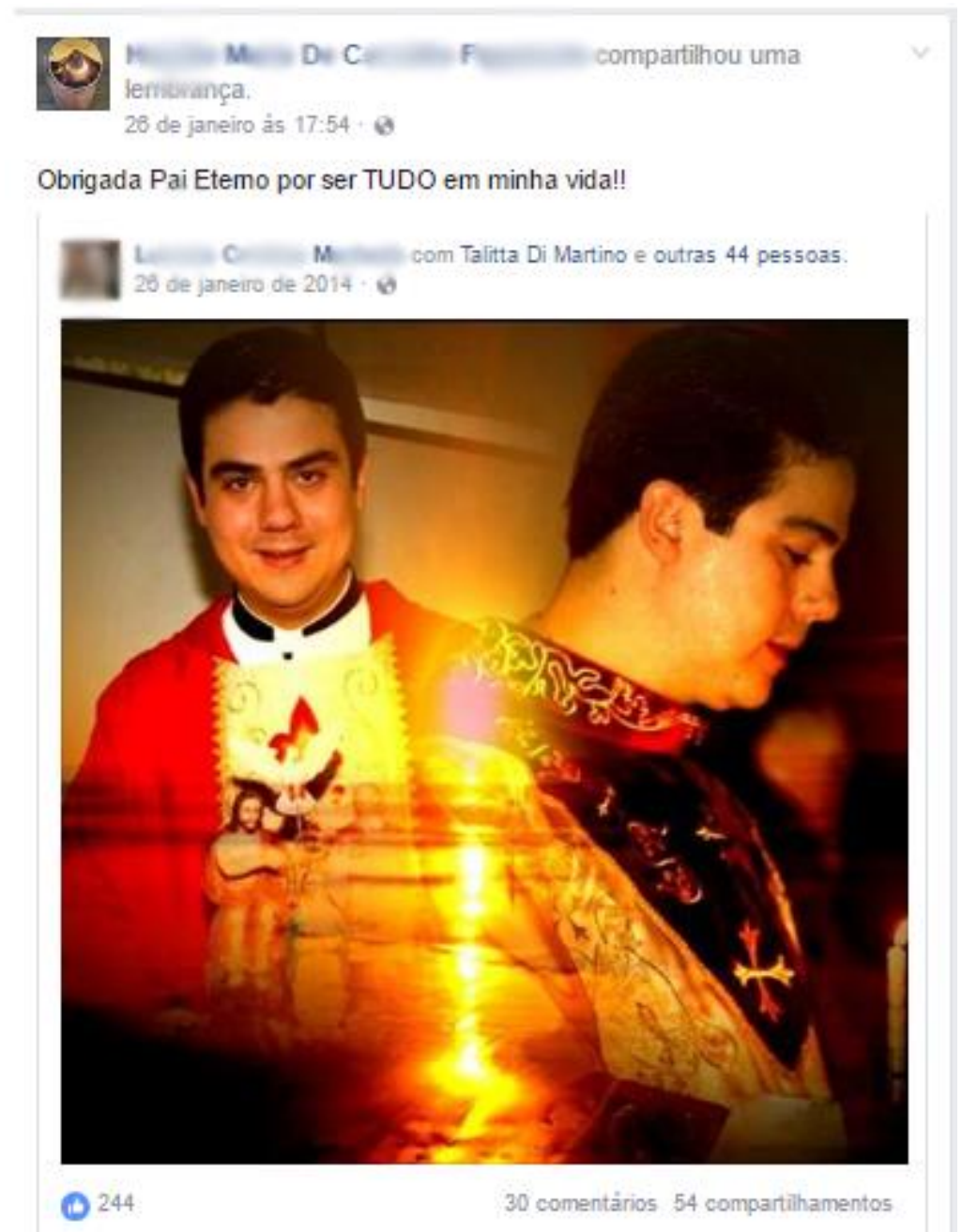

Figura 9 - Imagem de perfil de devota na rede social Facebook

\subsection{O milagre e a dádiva}

Os ciclos novenários correspondem a nove dias de orações. Neles o Padre faz, através da televisão, leituras de passagens de orações da novena do Divino Pai Eterno, acompanhado por um momento de leitura do testemunho dos devotos e da bênção da água. O programa é exibido durante as manhãs na TV, bem como é disponibilizado em vídeo no site oficial da AFIPE e no aplicativo móvel. 


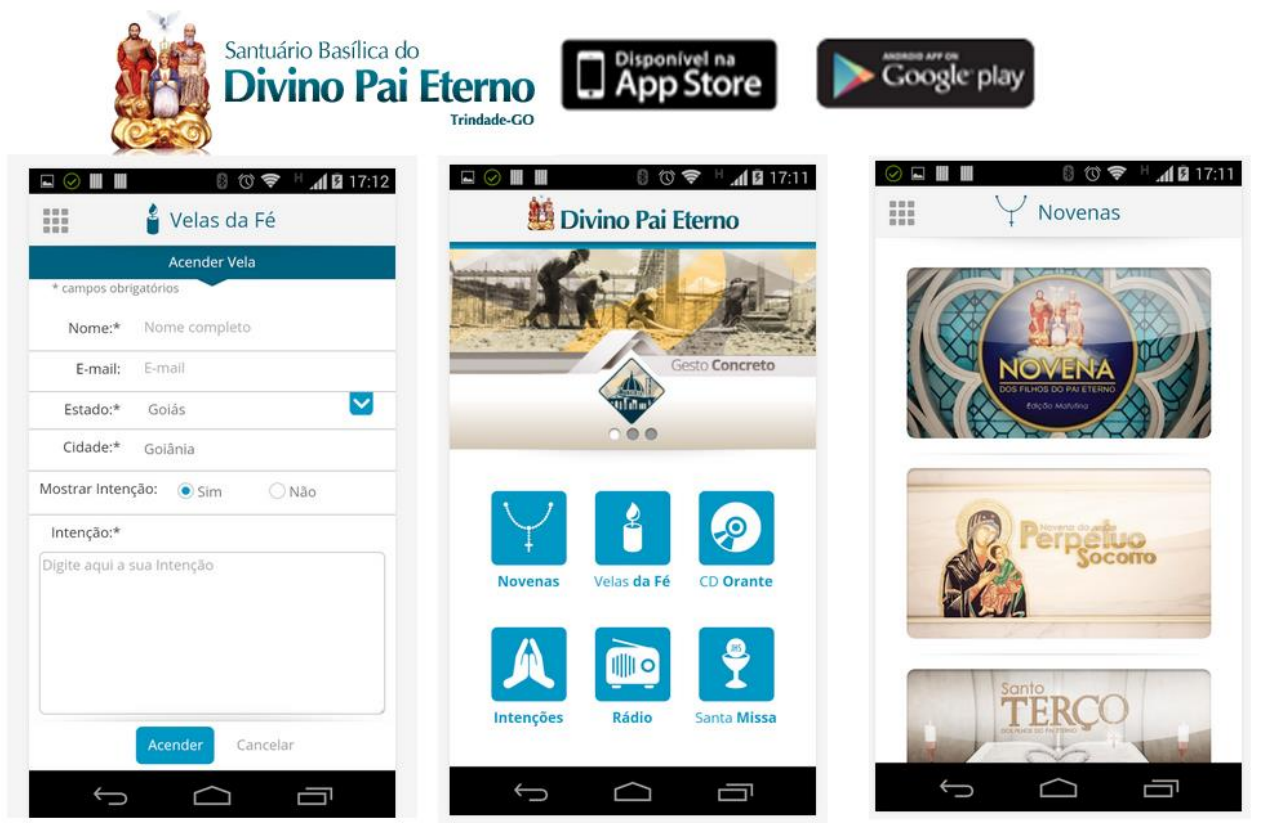

Figura 10 - Print Screen capturado do aplicativo “Pai Eterno” em versão para Android - 02/08/2015

O site oficial do Pai Eterno está disponível em português, inglês e espanhol. Reúne notícias sobre a rotina no Santuário e na Igreja Matriz, além de links de transmissão das missas, vídeos e fotos de devotos visitando o templo e acompanhando as missas do Padre Robson.

Através da homepage é possível acender velas virtuais com pedidos na área "Velas da Fé" e deixar mensagens de "Testemunhos", podendo-se escolher em formulário entre tornar pública a mensagem ou apenas permitir que ela seja exibida de forma privada, que só a AFIPE pode visualizar.

As velas e os pedidos de "Intenções" de preces (públicas ou privadas) também se encontram acessíveis no aplicativo "Pai Eterno", disponível para plataformas móveis da Apple e Android. Entre outras funções, o aplicativo permite acessar as "Novenas", sendo possível assistir aos últimos rituais de três tipos de orações realizadas pelo Padre Robson: a "Novena dos Filhos do Pai Eterno", "Novena do Perpétuo Socorro" e o "Santo Terço".

Na seção "Santa Missa" são transmitidas ao vivo as missas realizadas no Santuário em Trindade. Na guia "Rádio" está localizada a transmissão 24 horas da Rádio Rede Pai Eterno de Comunicação, e, em “CD Orante”, o usuário do aplicativo pode escutar faixas do CD com orações e canções do Padre Robson de Oliveira.

O programa televisivo é caracterizado pela sua ação em torno da divulgação da doutrina religiosa, dos passos novenários e das orações para os devotos que assistem a ele 
através dos diferentes meios nos quais o programa é disponibilizado. O discurso de apresentação feito pelo Padre Robson toma como foco as formas de conversão para a fé religiosa e o alcance de curas através da intercessão do Padre junto a Deus, em prol do seu público devoto. Há, portanto, um movimento no discurso do Padre que remete à promessa de salvação, de cura do devoto espectador.

Robson pede em nome de Deus que o pedido do devoto (um processo ascendente) seja atendido, mas a dádiva neste instante é igualmente transcendental, ocupando um espaço simbólico individual do espectador.

Pedimos a proteção física e espiritual para as nossas vidas. Vamos, pois, meu irmão, minha irmã, suplicar ao Pai Eterno. Que nos guarde de todo o perigo deste mundo, que guarde a sua casa, que proteja também as pessoas que você ama. Familiares, amigos, crianças indefesas, idosos, os jovens, os trabalhadores, as donas de casa. [...] Meu irmão, minha irmã, que Deus coloque um anjo ao seu lado e ao lado daqueles que você pede, por quem você pede. [...] Senhor, eu vos peço, olhai por esse servo, por essa serva, com a vossa misericórdia, concedei proteção, Senhor, para a sua vida, corpo, alma. Que esteja um anjo da guarda sempre ao seu lado e ao lado das pessoas por quem ele pede. Senhor, confio a vós todas as necessidades, toda a vida deste meu irmão, desta minha irmã. Que assim seja (Padre Robson de Oliveira no Programa Novena dos Filhos do Pai Eterno - 10/11/2015). ${ }^{22}$

O Padre benze as intenções que são enviadas através de cartas pela caixa postal da AFIPE. Elas são postas sobre uma mesa e recebem uma oração com pedidos do Padre ao Divino Pai Eterno para que sejam atendidas. Robson faz referência também às pessoas que enviam suas intenções pelo aplicativo, site e outros meios. O sacerdote pede ao público que coloque um copo de água sobre o lugar onde está assistindo à Novena, para que o Pai Eterno abençoe esta água durante a oração que ele fará. Na sequência, pede que o público beba a água (ao mesmo tempo que ele bebe), dizendo aos espectadores que façam uma oração. Em seguida, já no final do programa, o Padre pede que participem como associados da AFIPE.

Antes de finalizar, eu queria dizer a vocês da importância que é fazer parte da Associação Filhos do Pai Eterno, essa família de amor e evangelização. Nós temos nos esforçado muito para levar o amor de Deus até tantos corações em todos os lugares por meio da nossa missão evangelizadora. Eu agradeço a você que abraçou conosco essa missão. Você que ainda não é membro dessa família, comece agora mesmo este caminho conosco, faça parte da AFIPE. Nós somos filhos do Divino Pai Eterno, cadastre-se agora pelo telefone [...] ou então através do nosso site www.paieterno.com.br. E acompanhe também o nosso trabalho pelo celular smartphone baixando o aplicativo Pai Eterno. Eu aguardo o seu cadastro, você que ainda não é membro, e se você já é membro, reze sempre conosco, mantenha sua

${ }^{22}$ Link para o vídeo do programa: www.youtube.com/watch?v=nDOZebWIItE 
fidelidade, me ajude a encontrar novos devotos para assim continuarmos a nossa obra de amor (Padre Robson de Oliveira no Programa Novena dos Filhos do Pai Eterno - 10/11/2015).

\section{INFERÊNCIAS TRANSVERSAIS}

A proposição ensaiada de pastoreio mediatizado é uma analogia com a pedagogia cristã de atrair devotos. No caso estudado, surge como uma metáfora para designar a transformação do campo religioso com o advento da mediatização da instituição religiosa, manifesta na incorporação das narrativas sociais ascendentes ao discurso religioso institucional, mediado pelo pastor-ator midiático. As configurações discursivas não são mais aquelas definidas por levar a mensagem de Deus - manifesta nas Escrituras Sagradas - aos seguidores, mas também incluem a incorporação da palavra, da vontade, das energias e emoções dos devotos à discursividade divina.

O pastoreio mediatizado emerge da configuração de circuitos mediáticos. Essa constituição de circuitos, agenciando meios diversificados, na perspectiva da regulação, não é um fenômeno que possa ser definido estrategicamente, mas sim um processo em curso, que pode ser observado. Esta constituição se configura por entrelaçamentos entre o social e o mediático, por matrizes mediáticas complexas, em rede, indeterminadas, incertas (FERREIRA, 2016). Atuar neste circuito marcado pela indeterminação e incerteza, na perspectiva da regulação, é um desafio para as instituições e organizações, inclusive religiosas.

A experiência mediática do campo neopentecostal no Brasil abriu caminho para a busca de respostas a essa questão. A experiência católica - como no caso estudado, mas também em Canção Nova - faz isso com suas especificidades no movimento carismáticomidiático. Ou seja, a Igreja Católica passa também, pelo movimento carismático, a dispor deste circuito midiático, com práticas em que aceita, como transversais, as invenções históricas das igrejas evangélicas marcadas também pelas relações carismáticas.

O carisma envolve a identificação de uma liderança. Nas igrejas neopentecostais, a liderança carismática é exercida pelo pastor, que se autodesigna mediador entre Deus, as Escrituras e o profano. Essa mediação, na Igreja Católica, é institucionalizada, despersonalizada, por uma estrutura atemporal, hierárquica e disciplinar, com funções, ordens e delegações. Nas relações religiosas carismáticas, os indivíduos se designam como referências e são reconhecidos como tal. Geram-se, assim, na Igreja Católica, dois espaços: um espaço de práticas e rituais consolidados e referenciados nos códigos escritos, e um espaço 
de práticas fundadas em rituais midiáticos, em que a visualidade e a oralidade passam a ser registros centrais nas interações com os devotos. A palavra de Deus se manifesta através da palavra do líder.

Nesse processo, portanto, podemos observar vários deslocamentos no campo religioso católico, que transforma a própria religiosidade: do vigário para o líder carismático; das narrativas bíblicas para novas narrativas, que se entrelaçam com narrativas sociais, configurando novas discursividades; da intimidade da confissão para a extimidade dos meios de visibilidade pública; dos meios de interação presenciais (marcados pelo discurso e conversação) e impressos para os meios televisivos (programação) e digitais em rede (interação), que incorporam as práticas anteriores no espaço midiático.

Mas este reconhecimento, é essencial destacar, não é o mesmo que vigorou nos meios de conteúdo (jornal e livro), rádio e televisão (de programação). Tem uma nova configuração, o que nos convida a um diagrama-hipótese (Figura 11) que condensa o objeto estudado:

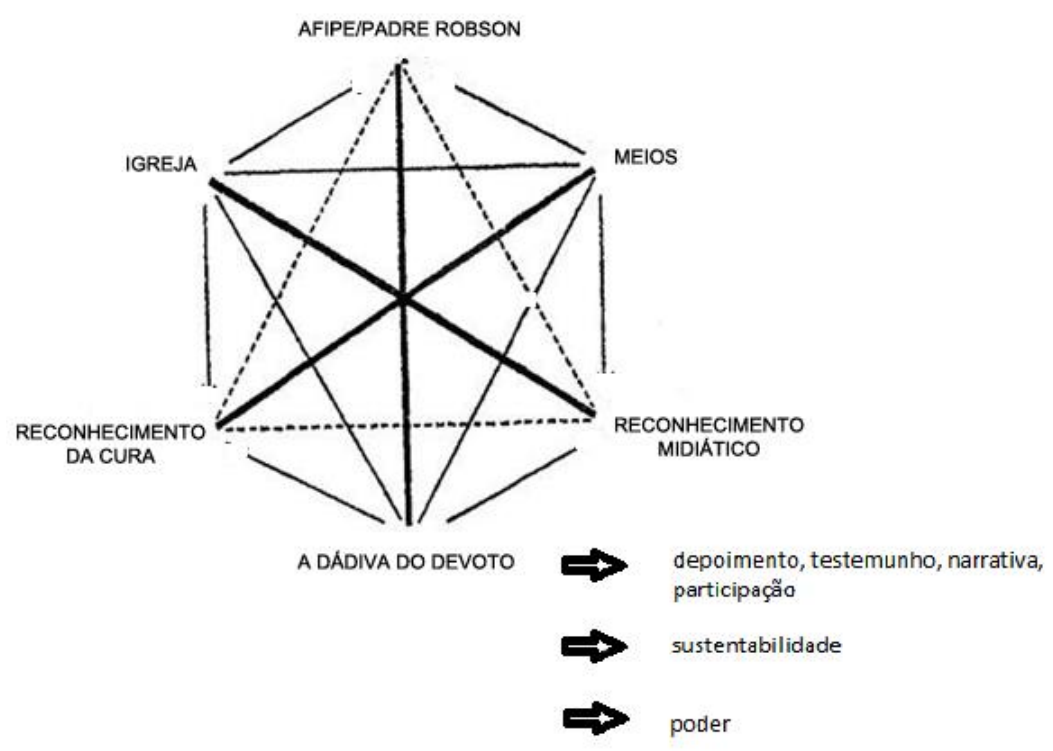

Figura 11 - Diagrama de relações inferidas Fonte: Cortes (2017, p. 27).

Este diagrama nos indicaria um duplo processo de reconhecimento (religioso e midiático) que se entrelaça, com remissões mútuas, de forma descendente e ascendente, configurando o pastoreio mediatizado. Sugerimos este diagrama para novas questões de pesquisa. Esse processo de reconhecimento em duplo vínculo pode ser a chave para uma revisita do templo, em seus formatos históricos anteriores (o templo presencial). Mas, 
conforme os objetivos desse artigo, o foco é a hipótese de que aí se configuram novas formas de processos de regulação de circuitos mediáticos, em que a organização religiosa manifesta a sua adaptação às novas configurações dos meios, seus usos sociais e interações potenciais. Essas novas formas de regulação são heterogêneas e multidimensionais (isso é, não são homogêneas, nem unidimensionais), demandando permanentes adaptações organizacionais, como mediações de atualização do vínculo por parte da instituição religiosa, na perspectiva de resolução do duplo vínculo.

Esse caso investigado evidencia um circuito que integra e se diferencia no campo religioso, pela imersão de indivíduos que se transformam em atores numa microconstelação, conectados, numa escala ampliada relativamente ao contato com o templo territorial. Não se trata mais do contato no tempo e espaço dos rituais desses territórios presenciais, mas daquele definido pela presença permanente, viável pelos meios digitais on-line. Adaptados a esse circuito, os leigos se incorporam em novas formas de regulação, com tempos e espaços de interação mediatizados, em que respostas, estímulos e reforços são trocados entre os interagentes e com os mediadores dos meios, condensados no líder religioso-carismático.

\section{REFERÊNCIAS}

AMARAL, Adriana. Manifestações da performatização do gosto nos sites e redes sociais: uma proposta pelo olhar da cultura pop. Revista Eco-PÓS, Rio de Janeiro, v. 17, p. 1-12, 2014.

BOURDIEU, Pierre. O poder simbólico. Lisboa: Editora Difel, 1989.

BRAGA, José Luiz. Circuitos versus campos sociais. In: MATTOS, Maria Angela; JANOTTI JUNIOR, Jeder; JACKS, Nilda (ed.). Mediação \& Mediatização. Salvador: EDUFBA, 2012. p. 3152.

BRAGA, José Luiz. A sociedade enfrenta sua mídia: dispositivos sociais de crítica midiática. São Paulo: Paulus, 2006.

CORTES, Dinis Ferreira. O duplo vínculo (midiático e religioso) nos circuitos-ambientes do pastoreio midiatizado. 2017. 140f. (Mestrado em Comunicação) - Programa de Pós-Graduação em Comunicação, Universidade do Vale do Rio dos Sinos (UNISINOS), São Leopoldo, 2017.

CUNHA, M. N. Elucidações contemporâneas nos estudos brasileiros em mídia e religião: a perspectiva das mediações culturais e comunicacionais. Revista FAMECOS (Online), v. 23, p. ID22280, 2016.

FERREIRA, Jairo. Mediatização: dispositivos, processos sociais e de comunicação. E-COMPÓS, Brasília, v. 10, p. 1-13, 2007.

FERREIRA, Jairo. O caso como referência do método: possibilidade de integração dialética do silogismo para pensar a pesquisa empírica em comunicação. InTexto, v. 27, p. 161-172, 2012. 
FERREIRA, Jairo. Adaptação, disrupção e regulação em dispositivos midiáticos. Matrizes, USP, v. 10, p. 135, 2016.

FERREIRA, Jairo. Uncertainty and indeterminacy in Brazilian social and media formation: references to think of the problem of recognition in the public space. ESSACHESS - Journal for

Communication Studies, v. 10, p. 269-287, 2017.

FERREIRA, Jairo. Meios, dispositivos e médium: genealogia e prospecções na perspectiva da mediatização. In: FERREIRA, Jairo; ROSA, Ana Paula; BRAGA, José Luiz; FAUSTO NETO, Antônio; GOMES, Pedro Gilberto (org.). Entre o que se diz e o que se pensa: onde está a mediatização? Santa Maria: FACOS-UFSM, 2018. v. 1, p. 283-298.

FERREIRA, Jairo. Como a circulação direciona os dispositivos, indivíduos e instituições? In: BRAGA, José Luiz; FERREIRA, Jairo; FAUSTO NETO, Antônio; GOMES, Pedro Gilberto (org.). Dez perguntas para a produção de conhecimento em comunicação. 2. ed. Santa Maria: FACOSUFSM, 2013. v. 1, p. 140-160.

FERREIRA, Jairo. O objeto, o método e a metodologia na pesquisa da circulação e midiatização (inferências a partir da obra Ethnographie de l'exposition). Revista FAMECOS (Online), 2020. No Prelo.

GOMES, Pedro Gilberto. Mediatização: um conceito, múltiplas vozes. Famecos, Porto Alegre, v. 23, n. 2, p. 1-20, 2016.

MARTINO, L. M. S. Mediatização da religião e esfera pública nas eleições paulistanas de 2012. Revista Brasileira de Ciência Política (Impresso), p. 7-26, 2014.

QUEIROZ, João. Classificações de signos de C. S. Peirce - de 'on the logic of science' ao 'syllabus of certain topics of logic'. Trans/Form/Ação, São Paulo, v. 30, n. 2, p.: 179-195, 2007.

PEIRCE, Charles Sanders. Collected Papers Ed. Charles Hartshorne. Cambridge, MA: Harvard University Press, 1958.

PROULX, Serge; FERREIRA, Jairo; DA ROSA, Ana Paula. Midiatização e redes digitais: os usos e as apropriações entre a dádiva e os mercados. 284. ed. SANTA MARIA: FACOS-UFSM, 2016. v. 1. $282 \mathrm{p}$.

VERÓN, Eliseo. Teoria da mediatização: uma perspectiva semioantropológica e algumas de suas consequências. Matrizes, São Paulo, v. 8, n. 1, p. 13-19, jan./jun. 2014.

VERÓN, Eliseo. O duplo vínculo como situação patogênica universal. In: VERON, Eliseo.

Fragmentos de um tecido. São Leopoldo: Editora Unisinos, 2005. p. 19-35.

VERÓN, Eliseo; LEVASSEUR, Martine. Ethnographie de l'exposition: l'espace, le corps et le sens. Paris: Centre Georges Pompidou, 1989.

WATZLAWICK, P. et al. Une logique de la communication. Paris: Seuil, 1972. 


\section{Jairo Ferreira}

Professor pesquisador no Programa de Pós-Graduação em Comunicação da Universidade do Vale dos Sinos (Unisinos), Pós-doutor em comunicação pela Universidade de Rosário (Argentina).

Dinis Ferreira Cortes

Doutorando e Mestre em Ciências da Comunicação pela linha de pesquisa Midiatização e Processos Sociais da UNISINOS (2017). Bolsista CAPES PROEX (2018-2022). Formado em Comunicação Social - Jornalismo pela UFN (2011).

\section{@ $\odot \Theta \odot$}

Esta obra está licenciada com uma Licença

Creative Commons Atribuição-NãoComercial-CompartilhaIgual 4.0 Internacional 